\title{
І.А. ПРОКОПЕНКО
}

\section{КРИТЕРЇ̈, ПОКАЗНИКИ ТА РІВНІ СФОРМОВАНОСТІ ГОТОВНОСТІ МАЙБУТНІХ УЧИТЕЛІВ ДО ЗДІЙСНЕННЯ ФАСИЛІТАЦЙНОЇ ВЗАЕМОДІЇ З УЧНЯМИ}

\author{
(C) Прокопенко I.A., 2019 \\ http://orcid.org/0000-0002-4775-8949 \\ http://doi.org/10.34142/2312-2471.2019.61.18
}

Стаття присвячена актуальній проблемі підготовки вчителів до здійснення фасилітаційної взаємодії з учнями. Системний підхід до проблеми дослідження вказує на те, щуо критерї, показники, рівні готовності майбутніх учителів до здійснення фасилітаційної взаємодї з учнями не можна розглядати як ізольовані, самодостатні елементи підготовки. Автором доведено, щуо перехід з рівня на рівень сформованої готовності характеризусться створенням нової системи відношень між елементами. Розроблено систему покомпонентних критерії та їх якісних показників сформованості готовності майбутніх учителів до здійснення фасилітаційної взаємодї з учнями відповідно до структури изього феномена, які відображають авторські модельні уявлення про його зміст та характеристики. На основі визначення суті поняття «готовність майбутніх учителів до здійснення фасилітаційної взаємодї з учнями» схарактеризовано його компоненти. Ціннісно-мотиваційний компонент оцінюється за допомогою мотиваційного критерію, когнітивний - змістового, діяльнісно-операційний - процесуального, рефлексійний - особистісно-рефлексійного. Визначені критерії характеризуються показниками: мотиваційний - ціннісне ставлення до майбутньої педагогічної професій, яке грунтується на засадах фасилітаційної взаємодїта оволодіння фасилітативною компетентністю; інтерес до опанування форм, методів та прийомів фасилітаційної взаємодї; потреба в досягненні успіху в професійній діяльності на засадах фасилітаційної взаємодї; змістовий - системність, дієвість, гнучкість; процесуальний сформованість умінь (діагностично-прогностичних, інтелектуальних, конструктивних, комунікативних); особистісно-рефлексійний - уміння здійснювати рефлексію, самооиінка, самоаналіз. Автором диференційовано рівні готовності майбутніх учителів до здійснення фасилітаційної взаємодії з учнями на основі традиційної триступеневої градації (високий, середній, низький). На основі проведеного аналізу автором розкрито суть змісту готовності майбутніх учителів до здійснення фасилітаційної взаємодії 3 учнями, схарактеризовано компоненти готовності та обгрунтовано критерї, показники та рівні сформованості означуваної готовності.

Ключові слова: підготовка, готовність, майбутній учитель, фасилітаційна взаємодія, учень, критерій, показник, рівень сформованості. 


\section{Prokopenko I.A. Criteria, Indicators and Formation Levels of Readiness of Future Teachers for Facilitation Interaction with School Students}

The article is devoted to the topical problem of preparing teachers for facilitation interaction with school students. A systematic approach to the research problem indicates that the criteria, indicators, levels of readiness of future teachers to carry out facilitation interaction with students can not be considered as isolated, selfsufficient elements of training. The author proves that the transition from the level of the formed readiness is characterized by the creation of a new system of relations between the elements. A system of component-by-component criteria and their qualitative indicators of the readiness of future teachers to facilitate interaction with students in accordance with the structure of this phenomenon, which reflect the author's model ideas about its content and characteristics. Based on the definition of the essence of the concept "readiness of future teachers to carry out facilitation interaction with school students» its components are characterized. The valuemotivational component is evaluated using a motivational criterion, cognitive semantic, activity-operational - procedural, reflective - personal-reflective. The defined criteria are characterized by indicators: motivational - value attitude to the future pedagogical profession, which is based on the principles of facilitation interaction; interest in mastering the forms, methods and techniques of facilitation interaction; the need to succeed in professional activities on the basis of facilitation interaction; semantic - system, efficiency, flexibility; procedural - the formation of skills (diagnostic-prognostic, intellectual, constructive, communicative); personalreflective - the ability to reflect, self-assessment, self-analysis. The author differentiated the levels of readiness of future teachers to engage in facilitation interaction with students. Based on the analysis, the author revealed the essence of the content of readiness the future teachers to facilitation interaction with school students, characterized the components of readiness and substantiated the criteria, indicators and formation levels of the indicated readiness.

Key words: preparation, readiness, future teacher, facilitation interaction, school student, criterion, indicator, formation level.

Постановка проблеми. Розвиток системи освіти вимагає підвищення уваги до майбутніх учителів, їх здатності реалізовувати свій потенціал в майбутній професійній діяльності 3 різними категоріями учнів. Одним 3 важливих компонентів такої підготовки виступає здатність майбутніх учителів здійснювати фасилітативну (таку, що підтримує, допомагає, спрямовує) взаємодію з учнями при організації освітнього процесу. Важливість підготовки майбутніх учителів до фасилітаційної взаємодії визначається такими чинниками: загальносвітовими тенденціями, спрямованими на забезпечення надання рівних можливостей здобувачам освіти незалежно від їх адаптивних можливостей до соціокультурного середовища в освіті; урахуванням своєрідності пізнавальних і комунікативних можливостей здобувачів освіти, спрямованим на попередження їх навчальної дезадаптації; стимулюванням 
саморозвитку, самовиховання кожного здобувача освіти 3 визнанням його унікальності; мотивуванням самореалізації кожного учня в процесі навчання, що вимагає особистісно орієнтованого підходу в освіті, який передбачає готовність майбутніх учителів до фасилітативної взаємодії 3 учнями; урахуванням потреб самовдосконалення майбутнього вчителя, здатного реалізовувати свій педагогічний потенціал при фасилітативній взаємодії 3 різними категоріями учнів.

Майбутній учитель, здатний до фасилітаційної взаємодії, зможе створювати на заняттях сприятливу атмосферу для вирішення освітніх завдань, паралельно сприяючи особистісному зростанню учнів (набуття ними не лише знань та професійних вмінь, але й м'яких навичок). Суб'єкт-суб'єктна освітня діяльність вимагає формування особистісних фасилітативних якостей та вмінь у процесі професійної підготовки майбутніх учителів. Розв'язання даної проблеми дозволить вчителю бути готовим здійснювати фасилітаційну взаємодію 3 учнями. Вищезазначене зумовлює необхідність підготовки майбутніх учителів у педагогічному закладі вищої освіти (ЗВО) до фасилітаційної взаємодії з учнями.

Аналіз основних досліджень і публікацій. 3 урахуванням важливості розвитку ідеї фасилітативної взаємодії в системі навчання означена проблема набула відзеркалення в науковій літературі. У контексті нашого дослідження необхідно було розкрити суть поняття «фасилітаційна взаємодія». Проведений аналіз наукової літератури показав, що вчені частково досліджували окремі аспекти, пов'язані 3 фасилітацією. Зокрема, фасилітаційне спілкування (Безлюдна, 2013; Коломійченко, 2010), педагогічна фасилітація (Гура, 2014; Курлянд, 2018), фасилітаційна компетентність (Гарьковець, 2016; Фокша, 2018), фасилітативний підхід (Волошко, 2016; Tharayil, 2018), фасилітативна підтримка (Нестеренко, 2014; Sykes, 2018) та ін.

Деякі дослідники вважають, що фасилітація спрямована на: досягнення визначених результатів освітньої діяльності (Bostrom, 1993; Clawson, 1993), стимулювання самої дії (Sapin, 1990), організацію процесу саме фасилітаторами (Hunter, 1994). Вчені переконані, що фасилітаційне спілкування орієнтоване на підвищення ефективності співпраці учасників, які беруть на себе відповідальність за виконання поставленого завдання (Brockett, 1983;

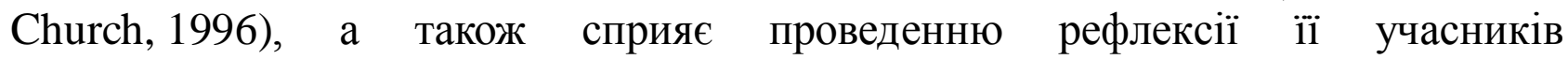
(Ichiyama, 1993).

Під час аналізу актуальної літератури (Прокопенко, 2017; Bens, 2018; Schwarz, 2017) ми також встановили, що інтерактивні, практичні, тренінгові форми завдань сприятимуть підвищенню рівнів показників сформованості готовності майбутніх учителів до фасилітаційної взаємодії з учнями, адже допомагатимуть набути не лише теоретичні знання на ментальному рівні, а й отримати практичний досвід, залучаючи тілесний та емоційний рівні.

Виділення невирішених раніше частин загальної проблеми. Водночас проведений аналіз наукової літератури надав підстави стверджувати, що теоретико-методичні питання забезпечення підготовки майбутніх учителів до 
здійснення фасилітаційної взаємодії з учнями не отримали в ній достатнього відображення та потребують уточнення критеріїв, показників та рівнів сформованості готовності майбутніх учителів до даного виду діяльності.

Мета статті - на основі аналізу наукової літератури визначити критерії, показники та рівні сформованості готовності майбутніх учителів до фасилітаційної взаємодії з учнями.

Виклад основного матеріалу. Вимоги сучасних освітніх стандартів усіх рівнів освіти передбачають виконання вчителем фасилітативної функції провідного компонента його професіоналізму, активності, конкурентоспроможності. При організації освітнього процесу слід вжити заходів для формування педагогічних колективів-команд, які працюють на засадах фасилітаційної взаємодії.

Фасилітаційну взаємодію в нашому дослідженні, спираючись на наукові праці вчених (Гельбак, 2011; Коломійченко, 2010; Roger, 1967 та ін.), визначаємо як суб'єкт-суб'єктну взаємодію, в межах якої відбувається налагодження такого емоційного контакту, створення такого освітнього середовища, що позитивно мотивує як до навчальної діяльності учнів, так i допомагає невимушеному спільному особистісному зростанню та самовдосконаленню вчителя та учня. Результатом підготовки майбутніх учителів до здійснення фасилітаційної взаємодії 3 учнями $\epsilon$ сформована готовність до даного виду діяльності.

Готовність майбутніх учителів до здійснення фасилітаційної взаємодії $з$ учнями визначаємо як інтегративну здатність особистості, що має системну організацію, складну, багаторівневу структуру і виступає як сукупність та взаємозв'язок ціннісно-мотиваційного, когнітивного, діяльнісно-операційного та рефлексійного компонентів, ступінь сформованості яких дозволяє майбутнім учителям продуктивно використовувати форми, методи, технології, засоби фасилітаційної взаємодії при вирішенні професійних завдань, удосконалювати свій досвід при їх застосуванні.

Аналіз цього визначення дозволяє виокремити в ньому характерні особливості фасилітативної взаємодії педагога 3 учнями. До них належать: безпосередні або опосередковані спільні дії суб'єкта-майбутнього вчителя (надалі суб'єкт 1) та суб'єкта-учня (надалі суб'єкт 2); позиція суб'єкта 1 щодо взаємодії - спрямовувати, ініціювати, підтримувати і сприяти конструктивному прояву суб' 'єкта 2; суб'єкту 1 при взаємодії сприймати суб' єкта 2 таким, яким він $\epsilon, 3$ урахуванням його особливостей в пізнавальній та позанавчальній діяльності; опанування суб'єктом 1 технологій фасилітаційної взаємодії щодо забезпечення реалізації індивідуально-творчого потенціалу суб'єкта 2, які водночас дають змогу суб'єкту 1 уникнути проявів професійного вигорання.

Розкриємо суть кожного компонента готовності, які ми встановили у наших комплементарних дослідженнях: изіннісно-мотиваційний (мотиви, мета; потреби в фасилітаційний взаємодії у майбутній професійній діяльності, вдосконаленні, самовихованні, саморозвитку; стимулювання майбутнього вчителя до фасилітаційної взаємодії); когнітивний (опанування знань щодо суті 
поняття «фасилітація» та розуміння проблеми організації фасилітаційної взаємодії у майбутній професійній діяльності); діяльнісно-операційний (вільне володіння навичками фасилітації, які ефективно впливають на формування готовності майбутніх учителів до фасилітаційної взаємодії; опанування технологій реалізації цінностей педагогічної діяльності, які лежать в іії основі); рефлексійний (самоаналіз і самооцінка своєї діяльності та поведінки, а також діяльності та поведінки учня). Визначені компоненти знаходять повсякденний прояв у процесі здійснення фасилітативної взаємодії вчителя з учнями.

Розкриваючи суть кожного компонента готовності, визначимо його критерії та показники. Важливо зазначити, що рівень сформованості кожного із визначених нами компонентів готовності до фасилітаційної взаємодії оцінюється відповідними критеріями. Для вирішення поставлених завдань виникає необхідність чіткого виділення та формулювання критеріїв i показників готовності учителів до здійснення фасилітаційної взаємодії 3 учнями, що не можуть буди обрані довільно, а мають грунтуватися на іiі структурно-функціональних компонентах.

Серед критеріїв і показників було обрано ті, що піддаються дослідженню, фіксуванню, опису та певним вимірам, оскільки існують предмети дослідження, пов'язані з глибинами душі, які неможливо точно обрахувати та інтерпретувати у відсотках, а лише через спостереження, співчуття дослідника тощо. Це стосується і сформованої готовності майбутніх учителів до здійснення фасилітаційної взаємодії з учнями, тому результативність вивчення у майбутнього вчителя сформованої готовності слід уважати настільки вірогідною, наскільки ці результати можуть бути математично та статистично опрацьовані.

Суть поняття «критерій» (від грец. krioterion) розглядається як засіб для судження, мірила, на підставі якого здійснюється оцінювання, визначення або класифікація явищ (Бусел, 2004: 465), показника - як його ознаки, доказу, свідчення (Бусел, 2004: 839), параметру - як конкретної ознаки, рівня - як ступеня якості величини розвитку явища (Бусел, 2004: 1032).

Визначення критеріїв, показників та параметрів грунтується на думці вчених про те, що критерії мають бути однозначними (однаково трактуватися в межах конкретного дослідження), адекватними (відповідними природі явища, що досліджується), обгрунтованими (правомірно диференціювати рівні розвитку явища), прогностичними (здатними визначати відносну стійкість кожного рівня), надійними (мінімізувати розходження при повторному оцінюванні); відповідати вимогам адитивності та відображати всі складові явища (Курлянд, 1993).

Вагомою у контексті нашого дослідження є думка О. Ліннік, яка вважає, що для вивчення складних систем краще обирати невелику кількість показників і параметрів для аналізу всіх компонентів та характеру зв'язків між ними, що виступають незалежними системними ознаками як явищами об'єктивними (Ліннік, 2017: 27-28). 
Враховуючи зазначені положення, було розроблено систему покомпонентних критеріїв та їх якісних показників сформованості готовності майбутніх учителів до здійснення фасилітаційної взаємодії з учнями відповідно до структури цього феномена, які відображають авторські модельні уявлення про його зміст та характеристики. Перш, ніж характеризувати критерії, зазначимо, що ціннісно-мотиваційний компонент готовності до фасилітаційної взаємодії майбутніх учителів з учнями закладів загальної середньої освіти оцінюється за допомогою мотиваційного критерію, когнітивний - змістового, діяльнісно-операційний - процесуального, рефлексійний - особистіснорефлексійного.

Визначені критерії знаходять повсякденний прояв у процесі здійснення фасилітативної взаємодії вчителя з учнями.

1. Мотиваційний критерій характеризує мотиваційний фундамент сформованої готовності майбутніх учителів до здійснення фасилітаційної взаємодії з учнями, може бути представлений такими показниками як:

1.1. Ціннісне ставлення до майбутньої педагогічної професії і бажання будувати власну майбутню професійну діяльність на засадах фасилітаційної взаємодії;

1.2. Інтерес до опанування форм, методів та прийомів фасилітаційної взаємодії;

1.3. Потреба в досягненні успіху в професійній діяльності на засадах фасилітаційної взаємодії.

2. Змістовий критерій відбиває рівень сформованості знань студентів щодо поняття «фасилітаційна педагогіка», усвідомлення переваг саме такого типу взаємодії, оволодіння фасилітативними педагогічними технологіями, а також умінням влучно, до ситуації приміняти набуті знання та навички.

Аналіз праць щодо вимірювання якості знань майбутнього вчителя (Краєвський, 1988; Москаленко, 1995) дозволяє стверджувати, що показники якості знань, у залежності від їх властивостей, об'єднуються в групи: предметно-змістова група включає такі показники як повнота, системність, узагальненість; змістово-діяльнісна - дієвість, міцність, мобільність; змістовоособистісна - гнучкість, глибина, стійкість.

У межах проблеми, що досліджується, не ставилося завдання перевірити якість знань майбутнього вчителя за всіма названими вище показниками, а лише за тими, які є необхідними для формування готовності майбутніх учителів до здійснення фасилітаційної взаємодії з учнями.

Цікава думка П. Москаленка (Москаленко, 1995), який стверджує, що: предметно-змістові показники якості знань відбивають суттєві особливості самого об'єкта - знання здобувачів освіти, за їх допомогою можна виявити якість засвоєння окремих аспектів матеріалу, що підлягає засвоєнню, зв'язків усередині нього, а також зв'язків між різними об'єктами змісту навчального матеріалу; змістово-діяльнісні показники описують результати послідовного опанування навчального матеріалу - актуалізацію знань, закріплення, застосування, перебудову і реконструкцію; змістово-особистісні показники 
відбивають результати застосування знань у самостійній позанавчальній або навчальній діяльності. Ми ж змістовий критерій перевіряємо за допомогою таких показників, як: системність; diєвість; гнучкість.

Системність засвоєних знань виявляться у ступені володіння понятійним апаратом та категоріальним фондом щодо фасилітаційної взаємодії з учнями, освоєнні фасилітативних технологій, розуміння доречності їх використання та усвідомлення вектору впливу, бачення причинно-наслідкових зв'язків.

Дісвість, як показник якості знань, характеризує результати застосування майбутнім учителем знань у нових навчально-педагогічних ситуаціях. Для цього йому необхідно актуалізувати знання суті об’єктів фасилітаційної взаємодії, що вивчаються, знайти способи оперування ними з метою отримання власних нових результатів.

Гнучкість як показник якості знань відображає можливості перебудови майбутнім учителем звичних дій, отриманих висновків. Виявляється в оригінальності підходу до аналізу педагогічної ситуації і можливості іiі переосмислення, в удосконаленні вже знайдених способів вирішення. Гнучкість - готовність до самостійного знаходження майбутнім учителем способу застосування знань при зміні ситуації або різних способів у тій самій педагогічній ситуації. Зауважимо, що гнучкість пов'язана із суб'єктністю особистості і виявляється тільки після того, як майбутній учитель засвоїв інформацію і вона стала властивістю його особистості. Даний показник може бути виявлений під час виконання творчих завдань, вирішення проблемних ситуацій, у дискусіях, диспутах тощо.

3. Проиесуальний критерій визначає міру сформованості: діагностичнопрогностичних, інтелектуальних, конструктивних, комунікативних вмінь, для формування i виявлення яких 3 фасилітативного погляду найкраще підійде метод кейсів.

4. Особистісно-рефлексійний критерій може бути представлений такими класичними показниками: умінням здійснювати рефлексію, самооцінку, проводити самоаналіз, що для педагога-фасилітатора є не рекомендованими, а обов'язковими видами діяльності, а також володіння проактивними методами запобігання і профілактики професійного вигорання

Розроблена система критеріїв та показників сформованості компонентів готовності майбутніх учителів до здійснення фасилітаційної взаємодії з учнями дозволила диференціювати рівні цього багатогранного новоутворення. Для цього використовувалася традиційна триступенева градація, в межах якої визначалися зони розподілу характеристик та якісних параметрів показників кожного 3 критеріїв. Залежно від міри їх прояву та відповідного ступеня розвиненості основних компонентів готовності майбутніх учителів до здійснення фасилітаційної взаємодії з учнями було визначено три рівні іiі сформованості у майбутніх учителів - високий; середній; низький (табл.1).

Таким чином, здійснення фасилітаційної взаємодії вчителя 3 учнями виступає важливим чинником його професійної педагогічної діяльності. 


\section{Таблиця 1}

\section{РІВНI СФОРМОВАНОСТІ ГОТОВНОСТІ МАЙБУТНІХ УЧИТЕЛІВ

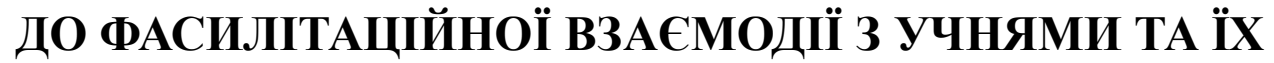 ХАРАКТЕРИСТИКА}

\begin{tabular}{|c|c|c|}
\hline № 3/II & Рівні & Характеристика \\
\hline 1 & Високий & 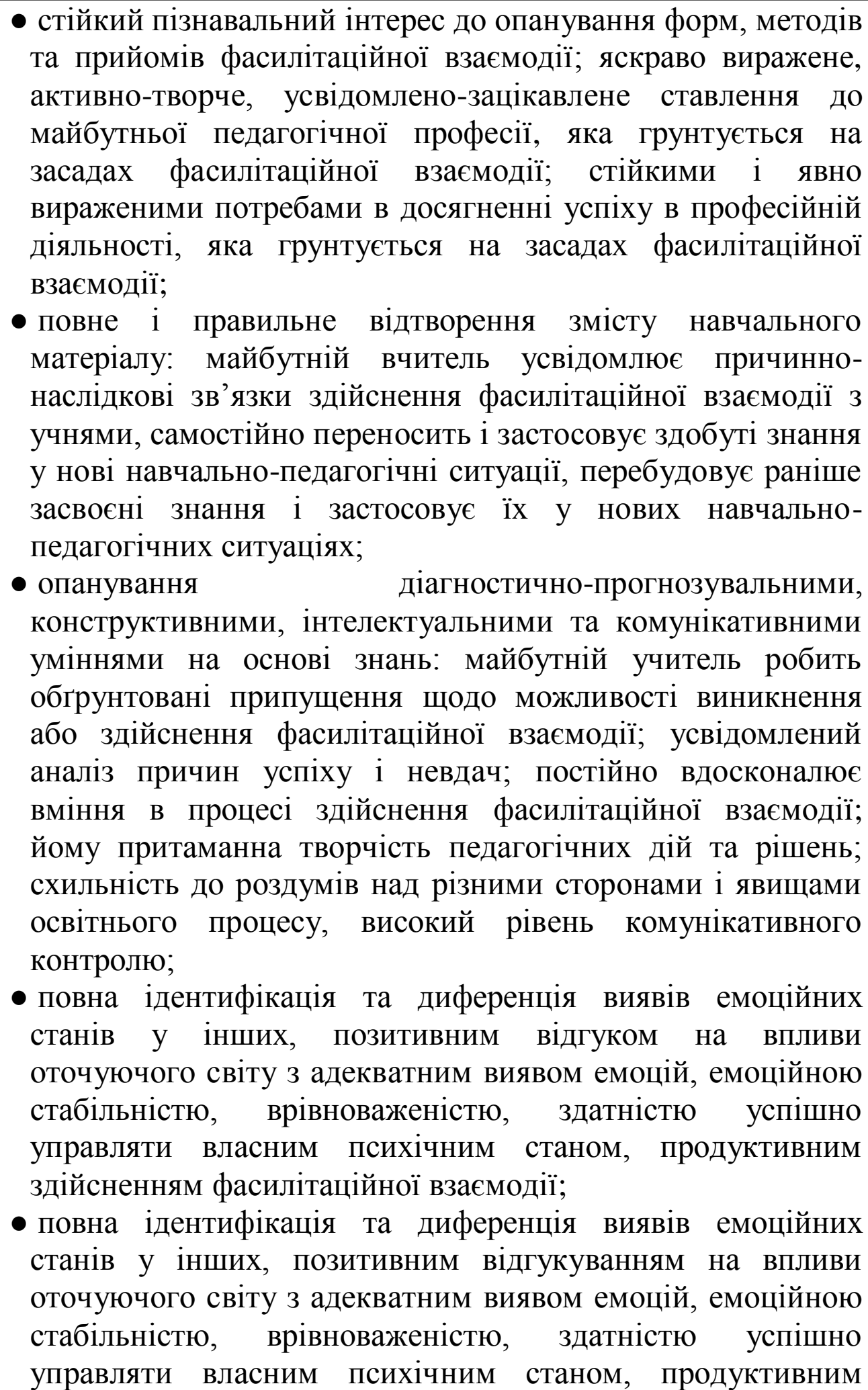 \\
\hline
\end{tabular}


здійсненням фасилітаційної взаємодії;

- постійне виявлення адекватної самооцінки, обгрунтованим порівнянням мети i завдань здійснення фасилітаційної взаємодії 3 отриманими результатами i самостійним проявом i коригуванням незначних відхилень від запланованого.

- короткочасний, частково реалізований у конкретних діях інтерес до здійснення фасилітаційної взаємодії; нестійкими i недостатньо вираженими потребами в іiі сформованості; загально позитивним, але здебільшого пасивним або ситуативним ставленням до педагогічної професії; активність виявляється ситуативно; виявляє, але не завжди реалізує мотиви досягнення;

- неповне, але здебільшого правильне відтворення змісту навчального матеріалу щодо здійснення фасилітаційної взаємодії 3 учнями; частковою перебудовою раніше засвоєних знань 3 фасилітаційної взаємодії та застосуванням їх у нових типових навчально-педагогічних ситуаціях або при підтримці педагога; поверховим розумінням теоретичних положень поряд iз недостатнім усвідомленням їх особистісної значущості;

- низка труднощів у процесі опанування діагностичнопрогнозувальних, конструктивних, інтелектуальних i конструктивних умінь: майбутній учитель частково передбачає результати діяльності, яка грунтується на здійсненні фасилітаційної взаємодії з учнями; обмежено прогнозує іiі труднощі, частково співвідносить завдання 3 умовами їх виконання, епізодично зіставляє реалізований i нереалізований потенціал; поверхово аналізує причини успіху i невдач, переважно несхильний до аналізу діяльності, обгрунтування, пояснення логіки вирішення проблемних ситуацій, йому притаманний середній рівень самоконтролю;

- адекватна емоційна виразність, схильність до етичних професійних переживань середньої інтенсивності та особистісної забарвленості без особливого інтересу, ініціативи, зацікавленості до здійснення фасилітаційної взаємодії з учнями. Загалом же майбутні вчителі не мають особливих труднощів при здійсненні фасилітаційної взаємодії у типових, стандартних умовах, але виявляють емоційну неврівноваженість, особливо у складних стресових ситуаціях, часткову дезадаптацію та втрату впевненості в собі у некомфортних умовах; 
- адекватна самооцінка, що виявляється не завжди, зіставляючи мету і завдання 3 отриманими результатами діяльності, майбутній учитель помічає відхилення, але береться до справи і дещо виправляє за умови підтримки i нагадування у процесі здійснення фасилітаційної взаємодії.

- виражене індиферентне або негативне ставлення до педагогічної професії, яка грунтується на засадах фасилітаційної взаємодії, виявленні активності в навчанні здебільшого у кризових ситуаціях, відсутності внутрішніх мотивів навчання, мінімальному виконанні нормативних навчальних вимог;

- неусвідомлене i механічне відтворення стереотипних суджень, знання позбавлені науковості та теоретичної бази, студенти не можуть пояснити i прокоментувати певні передумови здійснення фасилітаційної взаємодії, причинно-наслідкові зв'язки не встановлюють, їм притаманний фрагментарний характер застосування знань, набутих лише у стандартних умовах, відчувають труднощі застосування нових знань у нетипових навчальнопедагогічних ситуаціях, які долають лише за допомогою іншого суб'єкта освітнього процесу;

- допускається багато помилок у процесі опанування діагностично-прогнозувальними, конструктивними, інтелектуальними та комунікативними вміннями, що заважають процесу здійснення фасилітаційної взаємодії 3 учнями; студенти не вміють аналізувати процес i результати власної діяльності, пояснювати й обгрунтовувати педагогічні дії та рішення, замислюватися над їх суттю, вони відчувають суттєві складнощі у прогнозуванні результатів i труднощів навчальної діяльності, а також оптимальних способів їх вирішення;

- емоційна невиразність, скутість або емоційна «глухота» до здійснення фасилітаційної взаємодії, студенти не вміють контролювати вияв негативних або несхвалюваних емоційних реакцій та долати непродуктивні емоції та почуття навіть у нескладних та нестресогенних ситуаціях педагогічної діяльності;

- неадекватна занижена або завищена самооцінка результатів власної діяльності, яка підлягає коригуванню, майбутній учитель причини неякісних результатів власної діяльності не пов’язує із власним «Я», він може зіставляти мету і завдання із отриманими результатами діяльності, але 
у нього виникають труднощі з виявленням і коригуванням відхилень від запланованого, до того ж він рідко звертається за допомогою.

Висновки. Необхідність професійної підготовки майбутніх учителів до фасилітаційної взаємодії детермінована різноманіттям форм і видів педагогічної діяльності, специфікою роботи 3 учнями, які мають різні адаптаційні можливості в пізнавальній та позанавчальній діяльності. Вступаючи у взаємодію з різними категоріями учнів, які мають різні характеристики (вікові, національні, психологічні тощо), фасилітаційно підготовлений педагог сприяє природному процесу формування якісно нових взаємин, що грунтуються на емпатії, довірі, підтримці, а також стимулюванні можливостей кожного учня, в цілому - демократичної культури спілкування і взаємодії.

Формування готовності майбутніх учителів до фасилітаційної взаємодії 3 учнями - складний і тривалий освітній процес, який оцінюється сформованістю відповідних компонентів: ціннісно-мотиваційного, когнітивного, діяльнісноопераційного та рефлексійного. Відповідно кожен компонент оцінюється такими критеріями: мотиваційний, змістовий, процесуальний, особистіснорефлексійний.

Мотиваційний критерій характеризується ціннісним ставленням до майбутньої педагогічної професії; зацікавленністю до опанування технологій фасилітаційної взаємодії тощо; змістовий - системністю, дієвістю, гнучкістю; процесуальний - сформованістю умінь (діагностично-прогностичних, інтелектуальних, конструктивних, комунікативних); особистісно-рефлексійний - умінням здійснювати рефлексію, самооцінку, самоаналіз.

Визначено рівні готовності майбутніх учителів до здійснення фасилітаційної взаємодії 3 учнями на основі традиційної триступеневої градації: високий, середній, низький. На основі проведеного аналізу розкрито суть змісту готовності майбутніх учителів до здійснення фасилітаційної взаємодії з учнями, схарактеризовано компоненти готовності та обгрунтовано критерії, показники та рівні сформованості означуваної готовності.

Перспективи подальших розвідок полягають в теоретичному обгрунтуванні та експериментальній перевірці розробленої системи підготовки майбутніх учителів до здійснення фасилітаційної взаємодії з учнями.

\section{Jimepamypa}

1. Безлюдна, В. В. (2013). Фасилітація спілкування іноземною мовою як інноваційний вид формування комунікативної компетенції студентів. Вісник ЛНУ імені Тараса Шевченка, 14 (273), 82-86.

2. Бусел, В. Т. (укл. і ред). (2004). Великий тлумачний словник сучасної украӥнської мови. Київ : Ірпінь : ВТФ «Перун».

3. Волошко, Г. В. (2016). Фасилятивний підхід у діяльності викладача як сучасний напрям реформування вищої освіти. Педагогічні науки: теорія, історія, інноваційні технологї, 9 (63), 96-106. 
4. Гарькавець, С. О. (2016). Координати психологічного виміру фасилітативної компетентності педагога. Освіта на Луганщині, 1(42), 4-6.

5. Гельбак, А. М. (2011). Концептуальне обгрунтування програми фасилітативного впливу вчителя на розвиток комунікативних навичок у підлітків. Актуальні проблеми психології, 20, 96-99.

6. Гура, Т. В. (2014). Педагогічна фасилітація - механізм розвитку лідерського потенціалу студентів в умовах технічного університету. Теорія $i$ практика управління соџіальними системами, 3, 32-44.

7. Коломійченко, С. Ю. (2010). Підготовка майбутнього вчителя у вищих педагогічних навчальних закладах до організачії фасилітаційного спілкування з учнями. (Дис. ... канд. пед. наук). Харківський національний педагогічний університет імені Г. С. Сковороди.

8. Краевский, В. В. (1998). Методология педагогического исследования. Самара: Изд-во СамГПИ.

9. Курлянд, 3. Н., Богданова, І. М. (1993). Методика діагностики $i$ формування професійної усталеності майбутніх учителів. Одеса: ОДПІ ім. К. Д. Ушинського.

10. Курлянд, 3., Фокша, О., Поповський, Ю. (2018). Дослідження педагогічної фасилітації учителя як вітагенної педагогічної технології. Наука $i$ освіта, 4, 168-176.

11. Ліннік, О. О. (2017). Модель системи підготовки майбутнього вчителя до організації суб'єкт-суб'єктної взаємодії з учнями початкової школи. Вісник Луганського начіонального університету імені Тараса Шевченка. Педагогічні науки, 8 (313), 150-158.

12. Москаленко, П. Г. (1995). Навчання як педагогічна система. Тернопіль: ТДПІ.

13. Нестеренко, В. В. (2014). Фасилітативна підтримка студентів у процесі їхньої самореалізації і саморозвитку як суб'єктів самостійної навчальної діяльності. Педагогічні науки, 65, 248-254.

14. Прокопенко, I. А. (2017). Принципи та методи організації навчального тренінгу. Наукові записки кафедри педагогіки, 40, 141-150.

15. Фокша, О.М.(2018). Теоретичний аналіз проблеми формування фасилітаційної компетентності в майбутніх учителів. Науковий часопис імені М. П. Драгоманова. Серія 5. Педагогічні науки: реалї̈ та песпективи, 60, 203 207.

16. Bens, I. (2018). Facilitating with Ease!: Core Skills for Facilitators, Team Leaders and Members, Managers, Consultants and Trainers (4th Edition). New Jersey: Wiley \& Sons.

17. Bostrom, R., Anson, R. and Clawson, V. (1993). Group Facilitation and Group Support Systems. New York : Macmillan Publishing Company.

18. Brockett, R. (1983). Facilitator Roles and Skills. Lifelong Learning: the adult years, 6(5), 7-9.

19. Church, A. H., Waclawski, J. and Burke, W. W. (1996). OD Practitioners as Facilitators of Change. Group \& Organisation Management, 21(1), 22-66. 
20. Clawson, V. K., Bostrom, R. P. and Anson, R. (1993). The Role of the Facilitator in Computer-Supported Meetings. Small Group Research, 24(4), 12-18.

21. Hunter D. F., Bailey A. F. and Taylor, B. M. (1994). The Art of Facilitation. Auckland :Tandem Press.

22. Ichiyama, M. A. (1993). The Reflected Appraisal Process in Small-Group Interaction. Social Psychology Quarterly, 56(2), 87-99.

23. Roger, C. K. (1967). The interpersonal relatoinship in the facilitation of learning humanazing education. Boston : Houghton Mifflin.

24. Sapin, K. and Watters, G. (1990). Learning From Each Other. Manchester : The William Temple Foundation.

25. Schwarz, R. (2017). The Skilled Facilitator: A Comprehensive Resource for Consultants, Facilitators, Coaches and Trainers (3rd Edition). New Jersey: Jossey-Bass.

26. Sykes, P. and Gachago, D. (2018). Creating "Safe-ish" Learning Spaces Attempts to Practice an Ethics of Care. South African Journal of Higher Education, 32(6), 83-98. DOI: 10.20853/32-6-2654

27. Tharayil, S. et al. (2018). Strategies to Mitigate Student Resistance to Active Learning. International Journal of STEM Education, Volume: 5. Article Number: UNSP 7. DOI: 10.1186/s40594-018-0102-y

\section{References}

1. Bezliudna, V. V. (2013). Fasylitatsiia spilkuvannia inozemnoiu movoiu yak innovatsiinyi vyd formuvannia komunikatyvnoi kompetentsii studentiv [Facilitation of communication in a foreign language as an innovative type of formation of students' communicative competence]. Visnyk LNU imeni Tarasa Shevchenka [Bulletin of Taras Shevchenko LNU], 14(273), 82-86. (in Ukrainian).

2. Velykyi tlumachnyi slovnyk suchasnoi ukrainskoi movy [Large explanatory dictionary of the modern Ukrainian language]. (2004). ukl. i hol. red. V. T. Busel. K. : Irpin : VTF «Perun». (in Ukrainian).

3. Voloshko, H. V. (2016). Fasyliatyvnyi pidkhid u diialnosti vykladacha yak suchasnyi napriam reformuvannia vyshchoi osvity [Facilitative approach in the activities of the teacher as a modern direction of reforming higher education]. Pedahohichni nauky: teoriia, istoriia, innovatsiini tekhnolohii [Pedagogical sciences: theory, history, innovative technologies], 9 (63), 96-106. (in Ukrainian).

4. Harkavets, S. O. (2016). Koordynaty psykholohichnoho vymiru fasylitatyvnoi kompetentnosti pedahoha [Coordinates of the psychological dimension of the facilitative competence of the teacher]. Osvita na Luhanshchyni [Education in Luhansk region], 1 (42), 4-6. (in Ukrainian).

5. Helbak, A. M. (2011). Kontseptualne obgruntuvannia prohramy fasylitatyvnoho vplyvu vchytelia na rozvytok komunikatyvnykh navychok u pidlitkiv [Conceptual substantiation of the program of facilitative influence of the teacher on the development of communication skills in adolescents]. Aktualni problemy psykholohii [Current problems of psychology], 20, 96-99. (in Ukrainian). 
6. Hura, T. V. (2014). Pedahohichna fasylitatsiia - mekhanizm rozvytku liderskoho potentsialu studentiv $\mathrm{v}$ umovakh tekhnichnoho universytetu [Pedagogical facilitation - a mechanism for developing the leadership potential of students in a technical university]. Teoriia i praktyka upravlinnia sotsialnymy systemamy [Theory and practice of social systems management], 3, 32-44. (in Ukrainian).

7. Kolomiichenko, S. Yu. (2010). Pidhotovka maibutnoho vchytelia u vyshchykh pedahohichnykh navchalnykh zakladakh do orhanizatsii fasylitatsiinoho spilkuvannia z uchniamy. (Dys. ... kand. ped. nauk). [Preparation of future teachers in higher pedagogical educational institutions for the organization of facilitation communication with students (Thesis for e Degree Candidate of Pedagogical Scienses)]. Kharkivskyi natsionalnyi pedahohichnyi universytet imeni H. S. Skovorody. (in Ukrainian).

8. Kraevskij, V. V. (1998). Metodologiya pedagogicheskogo issledovaniya [Methodology of pedagogical research]. Samara : Izd-vo SamGPI. (in Russian).

9. Kurliand, Z. N., Bohdanova, I. M. (1993). Metodyka diahnostyky i formuvannia profesiinoi ustalenosti maibutnikh uchyteliv [Methods of diagnosis and formation of professional stability of future teachers]. Odesa : ODPI im. K. D. Ushynskoho. (in Ukrainian).

10. Kurliand, Z., Foksha, O., Popovskyi, Yu. (2018). Doslidzhennia pedahohichnoi fasylitatsii uchytelia yak vitahennoi pedahohichnoi tekhnolohii [Research of pedagogical facilitation of the teacher as vitagenic pedagogical technology]. Nauka i osvita [Science and education], 4, 168-176. (in Ukrainian).

11. Linnik, O. O. (2017). Model systemy pidhotovky maibutnoho vchytelia do orhanizatsii subiekt-subiektnoi vzaiemodii z uchniamy pochatkovoi shkoly [Model of the system of preparation of the future teacher for the organization of subject-subject interaction with primary school students]. Visnyk Luhanskoho natsionalnoho universytetu imeni Tarasa Shevchenka. Pedahohichni nauky [Bulletin of Luhansk Taras Shevchenko National University. Pedagogical sciences], 8 (313), 150-158. (in Ukrainian).

12. Moskalenko, P. H. (1995). Navchannia yak pedahohichna systema [Learning as a pedagogical system]. Ternopil : TDPI. (in Ukrainian).

13. Nesterenko, V. V. (2014). Fasylitatyvna pidtrymka studentiv u protsesi yikhnoi samorealizatsii i samorozvytku yak subiektiv samostiinoi navchalnoi diialnosti [Facilitative support of students in the process of their self-realization and self-development as subjects of independent educational activity]. Pedahohichni nauky [Pedagogical sciences], 65, 248-254. (in Ukrainian).

14. Prokopenko, I. A. (2017). Pryntsypy ta metody orhanizatsii navchalnoho treninhu [Principles and methods of organizing training]. Naukovi zapysky kafedry pedahohiky [Scientific notes of the department of pedagogy], 40, 141-150. (in Ukrainian).

15. Foksha, O. (2018). M. Teoretychnyi analiz problemy formuvannia fasylitatsiinoi kompetentnosti $\mathrm{v}$ maibutnikh uchyteliv [Theoretical analysis of the problem of formation of facilitation competence in future teachers]. Naukovyi chasovys imeni M. P. Drahomanova. Seriia 5. Pedahohichni nauky: realii ta 
pespektyvy [Scientific journal named after M. P. Drahomanov. Series 5. Pedagogical sciences: realities and perspectives], 60, 203 -207. (in Ukrainian).

16. Bens, I. (2018). Facilitating with Ease!: Core Skills for Facilitators, Team Leaders and Members, Managers, Consultants and Trainers (4th Edition). New Jersey: Wiley \& Sons. (in English).

17. Bostrom, R., Anson, R. and Clawson, V. (1993). Group Facilitation and Group Support Systems. New York : Macmillan Publishing Company. (in English).

18. Brockett, R. (1983). Facilitator Roles and Skills. Lifelong Learning: the adult years, 6 (5), 7-9. (in English).

19. Church, A. H., Waclawski, J. and Burke, W. W. (1996). OD Practitioners as Facilitators of Change. Group \& Organisation Management, 21 (1), 22-66. (in English).

20. Clawson, V., Bostrom, R. and Anson, R. (1993). The Role of the Facilitator in Computer-Supported Meetings. Small Group Research, 24 (4), 12-18. (in English).

21. Hunter D. F., Bailey A. F., Taylor B. M. (1994). The Art of Facilitation. Auckland :Tandem Press. (in English).

22. Ichiyama, M. A. (1993). The Reflected Appraisal Process in Small-Group Interaction. Social Psychology Quarterly, 56 (2), 87-99. (in English).

23. Roger C. K. (1967) The interpersonal relatoinship in the facilitation of learning humanazing education. Boston : Houghton Mifflin. (in English).

24. Sapin, K. and Watters, G. (1990). Learning From Each Other. Manchester : The William Temple Foundation. (in English).

25. Schwarz, R. (2017). The Skilled Facilitator: A Comprehensive Resource for Consultants, Facilitators, Coaches and Trainers (3rd Edition). New Jersey: Jossey-Bass. (in English).

26. Sykes, P.; Gachago, D. (2018). Creating "Safe-ish" Learning Spaces Attempts to Practice an Ethics of Care. South African Journal of Higher Education, 32 (6), 83-98. DOI: 10.20853/32-6-2654 (in English).

27. Tharayil, S. et al. (2018). Strategies to Mitigate Student Resistance to Active Learning. International Journal of STEM Education, 5:7. DOI: 10.1186/s40594-018-0102-y (in English). 